\title{
The well-being of families in Canada's future
}

\author{
Benoît Laplante ${ }^{1}$
}

\begin{abstract}
The author argues that the well-being of families in Canada's future is uncertain because families are losing the central position that was traditionally theirs in society. Most of the changes that occurred in and around families over the last third of the 20th century came from changes in values (from survival to personal development, from collectivity-oriented to individualoriented), in gender relations (women's rising education, labour force participation, and economic independence), and in the legal framework that deals with family life. Such changes are still having an impact on families, which will likely not diminish. But more than anything else, Canadian society is moving toward a model in which immigration rather than reproduction is the main source of population growth, thus reducing the importance of the family in policy development. This, and the increasing political importance given to environmental issues, might further displace the family as a priority for policymaking and the allocation of public resources, and thus impair the future well-being of families in this country.
\end{abstract}

Keywords: family; policy; reproduction; immigration; environmental issues.

\section{Résumé}

L'auteur soutient que le bien-être des familles canadiennes est loin d'être assuré à long terme parce que la famille, en tant qu'institution, perd aujourd'hui la position centrale qui était traditionnellement la sienne. La plupart des changements survenus dans et autour des familles au cours du dernier tiers du XXe siècle ont été la conséquence de changements dans les valeurs (de la primauté de la survie à celle du développement personnel, de la collectivité à l'individu), dans les rapports entre les sexes (l'éducation des femmes, leur activité et leur indépendance économique) et dans l'encadrement juridique de la vie familiale. Ces transformations se poursuivent et leur impact sur les familles ne diminuera probablement pas. À ceci s'ajoute le fait que la société canadienne a adopté un modèle où l'immigration remplace la reproduction comme source principale de la croissance démographique, réduisant encore plus l'importance de la famille pour l'élaboration des politiques. Ce changement, et l'importance croissante accordée aux questions environnementales, pourrait encore réduire la place de la famille en tant que priorité pour l'élaboration des politiques et l'allocation des ressources publiques, et ainsi compromettre le bien-être futur des familles.

Mots clefs: famille; politiques; reproduction; immigration; questions environnementales.

Making predictions about the family is a risky business. Predicting twenty years ago that most young couples in Quebec would live together and have their first child without being married would not have been too chancy, because both trends were already apparent. However, predicting that courts of law and the Parliament would extend marriage to same-sex couples would have seemed farfetched. This article reviews current trends before discussing emerging issues and future challenges of the well-being of families in Canada's future, and expanding our knowledge base.

1. Centre Urbanisation Culture Société, Institut national de la recherche scientifique, 385, rue Sherbrooke Est, Montréal, QC H2X 1E3; email: benoit.laplante@ucs.inrs.ca. 


\section{Current trends}

Unless current trends alter dramatically, several existing key trends will be influencing future Canadian families. The proportion of families that comprise two married people living with their common children will decrease. The proportion of couples living in common-law union is likely to increase, as will the proportion of children born to unmarried parents. Couples will probably spend part of their lives with interrupted marriages or in common-law unions. A large fraction of Canadian children will experience the separation or divorce of their parents. A large proportion of these children will spend a portion of their childhood in some form of shared custody, moving between homes. More children will live with step-parents and step-siblings. More children will live in families headed by a same-sex couple. Whether or not the proportion of children living with one parent will increase or remain stable is more difficult to guess. The proportion of mothers who work full-time will increase. There will be greater pressure on men to share equally in child-rearing and domestic chores. Families will demand conditions that favour a better balance between work and family life. In addition, unless there is a reversal of current trends, more people will live a large fraction of their adult lives without a spouse or partner, not only in their old age because of separation or death of a spouse, but also at younger ages that are usually considered ideal for family formation. The proportion of adults who never have children is also likely to increase.

This broad picture basically projects current trends into the future. It is simple approach, but the processes that govern these trends are too fundamental for us to expect the near future to be sharply different. This picture of the future and of the processes that produce it serves as a starting point for looking for the "weak signals" of emerging issues.

\section{Emerging issues and future challenges}

\section{Family flexibility and family formation}

About twenty years ago, cross-national comparative research showed that the association between having children and women's participation in the labour force had reversed. Fertility rates now tend to be higher in those countries where women are more likely to work. And now people are more likely to have children without being married (Héran 2013). Currently, there is also a positive effect of family flexibility on childbearing.

Why is there a positive effect? One reason is increasing out-of-wedlock births in several countries, where contraception and abortion are not readily available to poor young women. But the positive effect is mainly seen in Sweden, Norway, Denmark, France, New Zealand, and the United Kingdom, where women who have children without being married typically live in a stable relationship, similar to a common-law union, and typically have their children in their late 20s. These countries differ in their family policies, but they share two things. First, they tend to offer the same support to families whether the parents are married or not. Second, their private law does not equate marriage and common-law union to the point of imposing the sharing of assets and providing support payments to the former partner after separation. These developments have occurred by design in Sweden and from legislative inattention in France, where opposite-sex couples are often in "PACS" (in French, a pacte civil de solidarité, a very light form of registered partnership originally designed to accommodate same-sex couples). Increasingly, young couples seem more prone to have children in a legal context that allows them to do so while avoiding the judicial control and long-term obligations that marriage imposes. In other words, young couples seem more likely to have children in countries where their family will receive the same support regard- 
less of their marital status, and where they are left to manage their own relationship, including its economic aspects, with little interference from the government.

In Canada, governments do offer the same support to families whether the parents are married or not. Moreover, the evolution of legislation and case law has rigidified the new forms of family by equating marriage and common-law union. Most provinces have enacted statute law that imposes or promotes sharing of assets and spousal support to the former partner of a commonlaw union, similar to a marriage. Such provisions were originally devised to relieve hardship arising from the breakdown of common-law unions and, in most provinces, have been extended to aid the ex-partner who has accumulated less wealth during the union because of greater parental duties. The intention is generous but perhaps anachronistic. Today's young people might envision their relationship as a couple from a different perspective. Young adults—knowing that their relationship as a couple is likely to end at some point, and living in conditions in which both work intensity and wage differences between partners are on average much smaller than they used to be-might prefer a contractual relationship in which they keep control of their own future and avoid the risk of having to pay for someone else after the relationship ends. They might also worry about the risk of becoming dependent on someone else after the relationship ends, while sharing chores, child rearing, and contributions to family expenses as equally as possible as long as they live together. These are important emerging trends that require new knowledge and understanding. At present, family flexibility is a key aspect for Canada's changing families, with consequences for living arrangements and childbearing.

\section{The new social geography of family housing}

Families with young children typically want larger accommodations. They want one bedroom for each child, some inside space for kids to play, and some outside space for family activities. In metropolitan areas, they typically choose to settle in the suburbs, where land is cheaper and homes more affordable. This solution makes sense as long as land remains available for new housing, and transportation costs between home and work remain inexpensive. Several factors may make this more unlikely in the future.

Some factors are obvious. Land availability is constrained by geography and current use. This availability decreases as population grows. Prices increase and affordable suburbs become farther from the centre. Moving away from the centre increases the cost and duration of transport, eventually to the point that moving farther is not a practical solution. For contemporary families, the difficulty of finding the right place is compounded by having to commute from home to two different places of work.

For a variety of reasons that are not limited to environmental issues, current urban planning policies favour the building of new suburbs-within which there are short walking or bicycling distances - as well as increased density of city centres and areas close to main public transit lines. People who live in the newer suburbs, however, do not use public transportation more than those who live in older suburbs, which suggests that newer suburbs have little effect on commuting (CMHCorporation 2013). More importantly, other research shows that older higher-density areas in the inner city is closely associated with gentrification (Quastel et al. 2012). Housing stock in neighborhoods that are walkable, dense, and close to transit-basically, former working-class neighbourhoods-has become more suitable to dual-earners in higher-level occupations than households in sales, service, and manual occupations.

Family housing is not only an issue of affordability. Housing is a conundrum for low- and middle-income families because moving away from the centre is no longer a simple solution. Increasingly, the cost and duration of commuting are rising because of congestion, and policies 
that deter the use of private automobiles, while public transit is limited or not time-effective, and housing close to the centre has become too expensive.

For young couples, housing is a key factor in timing the birth of the first child. ${ }^{2}$ If the prospect of finding reasonable housing for a family becomes too difficult, couples may postpone or forego family formation. One wonders if this process, as much as or maybe more than affordability per se, explains British Columbia currently having the lowest fertility of all Canadian provinces.

\section{The increasing cost of children and the new intergenerational transmission of social status}

Over recent decades, Canada's federal and provincial governments have devised policies to reduce the proportion of children living in poverty. While this is a laudable achievement, it is not likely to provide equal opportunities for children from all social backgrounds. Parents usually want their children to do well. Recent research shows that over the last decades, achieving this goal increasingly depends on family wealth and non-economic resources (Corak 2013). The most obvious consequence of this trend is to increase the reproduction of social inequality. However, another consequence may be deterrence to family formation. As people become aware that getting jobs with good wages and good conditions increasingly depends on higher education, and that higher education depends on previous parental investments that are greater than what low- and middle-income families can afford, ordinary Canadians may come to the conclusion that properly raising children is beyond their means. This potential problem should not be underestimated. The comparatively high fertility in the United States should not be interpreted as evidence that the increasing cost of children does not deter people from having them, because a significant proportion of US children are born to young women who have restricted access to contraception and abortion, or to women who belong to ethnic groups with relatively high fertility norms. In Canada, young women have access to contraception and abortion, and they use them: their fertility is significantly below that of their American counterparts. Moreover, recent research shows that in Canada, on average, immigrant women do not have more children than the Canadian-born (Adsera et al. 2012; Street and Laplante 2014).

As described below, there are serious reasons to be concerned, because policies that alleviate child poverty rather than increase the well-being of low- and middle-class families may discourage young Canadians from starting a family.

\section{Childlessness as a norm}

Over the course of the 20th century, controlled fertility has become the norm in Canada. Births have been too few to replace the population for several decades. Individuals have fewer children, either by having smaller families or no children at all. Ravanera and Beaujot (2014) show that among Canadians born between 1947 and 1951, 14.4 per cent of women and 17.3 per cent of men remained childless, and that among Canadians born between 1972 and 1976 the proportions were 30.5 and 48.3 per cent, respectively. The latter were aged 30 to 34 at the time of the survey, and many of them may have had children afterwards. Still, these proportions are very high by historical standards. Estimates for more recent cohorts are lacking, but given the trends, childlessness might reach 50 per cent among men born after 1976. A century ago, the typical Canadian had several siblings and several children. Nowadays, the typical Canadian man has few siblings, if any, and might have no children at all. Childlessness is marginal no more and could be becoming the norm. This has a series of implications for individuals: the most obvious is that half of young Canadian men

2. Life cycle issues and concerns are discussed in greater detail in the article by Bélanger in this issue. 
would be lacking financial support and care from their children in their old age in a society where the market and the family are supposed to be the main providers of resources for the individual. Childlessness as a norm also has implications for the well-being of families. As more and more people do not have children, the family is being displaced from a central institution - the foundation of society, as it has been thought of since antiquity - to something secondary, if not yet marginal. This was feared in the 1930s, when low fertility and industrialization shook the Western family, and then the fears proved wrong (Davis 1937). This time, however, the most worrying indicator is childlessness in a context where immigration is a proven and favoured way of ensuring population replacement and population growth. Before our very eyes, the family might be losing its central position in Canadian society, along with its appeal and importance for political parties and the government. In a context where young families require more public goods and services, such as daycare and paid parental leaves, because both parents work and raising a family requires the earnings of two, lessening the political weight of the family might prove harmful for the well-being of families, and might convince even more people to forego forming a family.

\section{Children as goods rather than as citizens}

Canadian society has never subordinated the individual to the group in the way, say, that Japanese society is said to do or has traditionally done. Still, since the advent of neoliberalism in the early 1980s, increased individualization and commodification have fostered the reformulation of norms and behaviour around the paradigm of freedom of choice, in both its political and economic meanings. The family has been affected, as has everything else. In antiquity, having children was the duty of the citizen, as having children was the only way of perpetuating the political body. In Christian times, having children was the duty of the subject and of the believer. In modern times, having children has variously been imposed by the state (by outlawing contraception), encouraged (by granting subsidies or privileges), or, in a more social-democratic fashion, simply not discouraged - by shifting most of the cost of having children from the parents to the community. From the perspective of the economic analysis of low fertility proposed in the 1930s by Gunnar and Alva Myrdal, social-democratic state intervention is mild, one that simply allows people to have the children they want (Myrdal 1940; Myrdal 1968). ${ }^{3}$ From the neoliberal perspective, using taxes to provide services to families is another form of illegitimate intervention by the state. Individuals should be free to have children or not, and the state should not be imposing the burden of raising children on those without children, through taxation that funds education, daycare, paid parental leave, and family-oriented subsidies. Having children is a choice, not a duty, and there are other, less costly ways of ensuring the replacement of population and even its growth. This view may not be common or dominant, but it is not as marginal and extreme as it was even in the recent past, and it may contribute to a lessening of the idea of family as a central institution and a lessening of the political significance of families. This might be true even in Quebec, which is the only Canadian province that has developed an explicit set of family policies. This development occurred at a time when special circumstances - e.g., fast decline in fertility and fast diffusion of common-law union - and a wide acceptance of social-democratic views made such a development possible. Since then, society has grown accustomed to these circumstances, and a few decades of neoliberalism have lessened whatever consensus ever existed on the legitimacy of state intervention in such matters (see Dandurand 1987 and Saint-Pierre and Dandurand 2000).

3. The original report on low fertility and the need for state intervention was published, but never translated, as: Alva Myrdal and Gunnar Myrdal, Kris i befolkningsfragan (Crisis in the Population Question). Stockholm: Albert Bonniers Förlag, 1934. 


\section{Immigration as the only population policy}

Since Confederation, Canada has never had an explicit policy that would foster fertility. Fostering fertility was seen as undemocratic, and the economic analysis of below-replacement fertility that led to the development of the social-democratic Nordic welfare states has never been politically fashionable, and never entered into the Canadian psyche. Immigration has been the main if not the sole component of Canadian population policy. Immigration has obvious advantages. Immigrants are selected according to whatever criteria suit the political needs of the time; they are adults, so in theory they do not need long years of publicly funded education before entering the labour market; finally, they are not admitted if they have major health problems. Immigration is the major component of population growth since 1999 and is projected to account for almost all population growth from 2041 onwards (Bohnert et al. 2015). In 2016, Finance Minister Bill Morneau seemed ready to advocate within the government a plan developed by the Conference Board of Canada to push the Canadian population to 100 million people by 2100 by steadily increasing the number of immigrants to over 600,000 per year by 2050 (Ades et al. 2016). No country currently has such an extreme immigration policy, but the mere fact that such an idea might have been discussed at this level helps take the measure of the central role of immigration in Canadian policy-making and politics. The long Canadian tradition of using immigration as the main tool of population growth, the strong ideological commitment against the redistributive policies that Nordic countries have adopted to help people have the children they desire, and the current population projections in which almost all population growth will come from immigration in less than 30 years (Bohnert et al. 2015)—all these are likely to further lessen family as a central institution and the political significance of families.

\section{Human population as a threat to the planet}

The Canadian political culture is mainly of British extraction, and through this, it inherited a strong Malthusian orientation. The British Isles are islands of limited area, and, in the times of Malthus, it seemed impossible to increase food production in any way other than to put new land to use. The fallacy of the Malthusian argument has been proven again and again-productivity can increase yield in a way that matches the exponential growth pattern of the population and the consequences of deriving an anti-natalist policy from this Malthusian argument had been explored as early as in the 1930s, noticeably by Enid Charles (1934). ${ }^{4}$ The Malthusian reasoning is as simplistic and mesmerizing as the neoliberal ideology, and because of these features, it is resilient and adaptive. Its current avatar is a new version of radical or deep ecology, an ideological trend that goes beyond ecology as a science and beyond sustainability as a technological and economic paradigm, and well into the realm of utopia. One common tenet of this ideology is that there is no practical way to limit the harm that human activity does to the planet, and that human population must decrease by a large factor in order to save the living world. Discussing such an ideology in a piece on the well-being of families may seem farfetched, but it is not. This line of thought has taken root in activist groups, is pervasive in the scholarly work of some areas of the social sciences, and is permeating the thought of militants in a number of political parties at all levels of government. There is no way to estimate its current influence on the public agenda, but its ideas seem to be spreading, and they might add to the other trends that might lessen the political significance of families.

4. See Wargon (2005) for a more detailed account of Enid Charles. 


\section{Expanding our knowledge base}

\section{Family flexibility and childbearing}

Further research is needed on the relationship between family flexibility and fertility. Much of the philosophy that guided the evolution of family law in Canada over the last twenty years could be at odds with what today's young people expect, and family law could actually offset the effects of family policies. Canada may have turned the common-law union into a long-term liability that young people wish to avoid. By turning common-law union into something too similar to marriage, Canadian family law may deter young people from having children, and Canada may have inadvertently developed an anti-natalism policy. At present, both fertility and the proportion of children born to unmarried parents are relatively low in Canada compared to northern Europe. This is a trend that should be carefully watched and studied.

Things are a bit different in Quebec. The proportion of children born to unmarried parents has been hovering around 63 per cent since 2008, while the proportion of children whose father is not registered is about 2.6 per cent since 2006 (Institut de la statistique du Québec. 2018a). However, the total fertility rate, which had been increasing from 1.45 to 1.73 between 2000 and 2008, has been steadily decreasing since, and reached 1.59 in 2016 (Institut de la statistique du Québec. 2018b). Compared to couples living in other civil law jurisdictions, married couples in Quebec have very little freedom to decide the extent of the property they share. There are reasons to believe that many unmarried couples, who enjoy complete freedom in this matter, would not live together and would not have children if the law imposed to them the civil effects of marriage as they exist in Quebec. In this sense, Quebec's acceptance of common-law union as a framework for family formation is likely to have a real positive effect on fertility. However, this effect is not enough to reverse the declining trend. It seems limited to avoiding the fall to be even steeper. One may wonder what would happen to nuptiality and fertility if Quebec private law were modified to impose the civil effects of marriage to unmarried couples, something that came close to happen in 2013.

\section{Improving data sources}

The base for expanding knowledge on the Canadian family has shrunk during recent years. About 20 years ago, Statistics Canada and the Social Sciences and Humanities Research Council (SSHRC) reached an informal agreement. Statistics Canada would be responsible for collecting data on the Canadian society and making it available to researchers, and SSHRC would concentrate its resources on funding researchers to analyze these data. As part of this endeavour, Statistics Canada developed a large collection of longitudinal surveys, along with access to survey and census data, through the Research Data Centres. Several universities embarked on an unprecedented effort to train professors, researchers and graduate students in advanced statistical methods to make use of these data. The problem Canada does not face in the coming years is making the intellectual labour force more productive by increasing its skills - in fact, skill levels are better than before and training is ongoing. Rather, the problem is the dearth of data on Canada.

Adequate data sources have dwindled and new sources have not been developed. Statistics Canada has discontinued the production of some relevant aggregate data and considerably reduced the publication of basic analyses. As of 2008, Statistics Canada terminated the production of aggregate data on marriages and divorces, with no national source for the number of marriages and divorces. On other topics, although aggregate data are now more freely available than ever before through Statistics Canada's CANSIM database and other sources, researchers need to do the basic analytical work. For instance, basic comparative tables on critical demographic trends such 
as marriages or divorces require the compilation of original data from individual surveys. The set of longitudinal surveys initiated in the mid-1990s provided data similar to other advanced countries, enabling researchers to monitor and compare changes at work in Canadian society. Many of these surveys have ceased, however. Converting the sample portion of the 2011 Census into a voluntary survey increased costs and raised questions about the quality and comparability of important census data. The return of the long form of the census in 2016 was a relief, but the census alone is not enough to study the Canadian society and its transformations. SSHRC is unlikely to receive funding to support data gathering initiatives lead by researchers that would compensate for these losses. Canadian foundations have a tradition of helping charities, not doing social science research, which is considered to be a government responsibility. Finding a solution to this data dearth is the first and foremost step needed to improve and expand our knowledge base on the Canadian family. Statistics Canada and other federal and provincial departments are proposing the use of administrative data on a large scale. The idea is promising, but until now, the pace at which these data have become available to researchers has been far too slow to reverse the course.

\section{References}

Ades, J., D. Fields, A. Macdonald, and M. Stewart. 2016. A Long-Term View of Canada's Changing Demographics: Are Higher Immigration Levels an Appropriate Response to Canada's Aging Population? Ottawa: Conference Board of Canada. http://www.conferenceboard.ca/e-library/abstract.aspx? $\operatorname{did}=8282 \&$ AspxAutoDetectCookieSupport $=1$

Adsera, A., A.M. Ferrer, W. Sigle-Rushton, and B. Wilson. 2012. Fertility patterns of child migrants: Age at migration and ancestry in comparative perspective. Annals of the American Academy of Political Science and Social Science 643(September):160-239.

Bohnert, N., J. Chagnon, and P. Dion. 2015. Population Projections for Canada (2013 to 2063), Provinces, and Territories (2013 to 2038). Cat. no. 91-520-X. Ottawa: Statistics Canada.

CMHC (Canada Mortgage and Housing Corporation). 2013. Comparing Canadian New Urbanist and Conventional Suburban Neighbourhoods (Updated). Research Highlight Socio-economic Series 13-002. Ottawa: CMHC. https://www.cmhc-schl.gc.ca/odpub/pdf/67802.pdf

Charles, E. 1934. The Twilight of Parenthood: A Biological Study of the Decline of Population Growth. London: Watts and Company.

Corak, M. 2013. Income inequality, equality of opportunity, and intergenerational mobility. Journal of Economic Perspectives 27(3):79-102.

Dandurand, R.B. 1987. Une politique familiale: enjeux et débats. Recherches Sociographiques 28(23):349-69.

Davis, K. 1937 [1997]. Reproductive institutions and the pressure for population. Population and Development Review 23(3):611-24.

Héran, F. 2013. Fertility and Family-Support Policies: What Can We Learn from the European Experience? Keynote speech, Opening ceremony, IUSSP, Busan (Republic of Korea), 26 August 2013. https://iussp.org/sites/default/files/event_call_for_papers/Keynote_H\%C3\%A9ran_ IPC\%202013_ENGLISH.pdf

Institut de la statistique du Québec. 2018a. Naissances selon l'état matrimonial des parents, Québec, 1951-2016. http://stat.gouv.qc.ca/statistiques/population-demographie/naissancefecondite/410.htm 
2018b. Taux de fécondité selon le groupe d'âge de la mère, indice synthétique de fécondité et âge moyen à la maternité, Québec, 1951-2016. http://stat.gouv.qc.ca/statistiques/populationdemographie/naissance-fecondite/402.htm

Myrdal, A. 1968. Nation and Family: The Swedish Experiment in Democratic Family and Population Policy. Cambridge, MA: The M.I.T. Press.

Myrdal, G. 1940. Population: A Problem for Democracy. Cambridge, MA: Harvard University Press.

Quastel, N., M. Moos, and N. Lynch. 2012. Sustainability-as-density and the return of the social: The case of Vancouver, British Columbia. Urban Geography 33(7):1055-84.

Ravanera, Z.R., and R. Beaujot. 2014. Childlessness of men in Canada: Result of a waiting game in a changing family context. Canadian Studies in Population 41(1-2):38-60.

Saint-Pierre, M-H., and R.B. Dandurand. 2000. Axes et enjeux de la politique familiale québécoise. Montréal: INRS-Culture et Société.

Street, M.C., and B. Laplante. 2014. Pas plus, mais après! L'immigration, le calendrier de la constitution de la famille et les méthodes d'estimation de la fécondité. Cabiers québécois de démographie 43(1):35-68.

Wargon, S. 2005. Legacy of Enid Charles, 1894-1972. Canadian Studies in Population 32(2):137-53. 